\title{
Marine Mammal Monitoring on Guam
}

\author{
Robert Weybright McNulty*, Biology
}

\begin{abstract}
Data on marine mammals, specifically information on their stock numbers, seasonal migrations, population structure, habitat use, and behaviors is limited. This study of island-associated resident pods of the long nosed spinner dolphin (Stenella longirostris) was conducted near the island of Guam, part of the Mariana Archipelago, south of Japan. A proposed expansion of United States military facilities in Guam may adversely affect these spinner dolphins through the increases in training activity, population growth, coastal development, and tourism associated with military growth in an area. This study compiles historical and current data on marine mammal sightings and behaviors to study possible impact of U.S. military presence. The long nosed spinner dolphins (S. longirostris) are of particular interest because of their proximity to shorelines, their habitat use, and their daily activity schedule. Current data was collected from interviews and sighting events. Standard photo documentation and field survey protocols developed by the National Marine Fisheries Service (NMFS) Pacific Islands Fisheries Science Center (PIFSC) were used. This study created a preliminary marine mammal database for Guam and has expanded the limited information available. In addition, sighting information was used along with geographical information system (GIS) software to combine NOAA benthic habitat maps with multibeam bathymetry to gain a better understanding of the habitats occupied by documented species. Preliminary results suggest that S. longirostris populations in Guam have similar circadian and seasonal rhythms as Hawaiian S. longirostris populations. The results also demonstrate that Guam spinner dolphins show a preference for clear, relatively shallow open water bays with underlying, unconsolidated sediment (sandy bottoms). An increase in military use of shallow bays and dolphin-associated ecotourism could therefore negatively impact resident populations of the Guam spinner dolphins.
\end{abstract}

\section{INTRODUCTION}

Information on the ecology and behavior patterns of marine mammal populations is minimal. This study focuses on compiling and analyzing data on the seasonality, diversity,

*Robbie McNulty, is graduating in June 2013 from the University of Oregon with a bachelor's degree in biology and is now finishing work on his biology honors thesis. After graduation, McNulty plans to travel to Panama for a marine biology class at the Smithsonian's Tropical Research Institute. He plans to stay after the class and intern at various marine stations in South America and the Pacific in order to develop a graduate project oriented in sustainable marine ecosystem management. Direct correspondence to localhero@abcglobal.net. 
population structure, habitat use, and behavior of marine mammal populations due to the critical need for increased scientific understanding of environmental threats to the population dynamics and health of marine mammals surrounding Guam. Guam is part of the Mariana Archipelago, a chain of islands between Japan and Papau New Guinea. The National Marine Fisheries Service's (NMFS) Pacific Islands Fisheries Science Center (PIFSC) is particularly interested in collecting marine mammal information on populations of spinner dolphins which inhabit the near-shore waters of the island. Spinner dolphins are a pantropical species found in "all tropical and most subtropical waters around the world" and, in many cases, can be the most common small cetacean in tropical waters (Perrin 2009). Because of their distribution and behavior patterns, spinner dolphin populations make an excellent case study of the impacts of human activity.

Island-associated spinner dolphins, such as those populations found in Hawaii and other central and western Pacific islands, prefer shallow, protected bays to rest and socialize in during the day. They typically move offshore during a transitional period before nightfall, when they feed in open water (Norris et al. 1994; Reeves et al. 1999; Benoit-Bird and Au 2003; Lammers 2004; Karczmarski et al. 2005; Oremus et al. 2007; Johnston et al. 2008). The daily circadian pattern of island-associated spinner dolphins is shown in Figure 1, below.

Figure 1: Circadian movement pattern of spinner dolphins

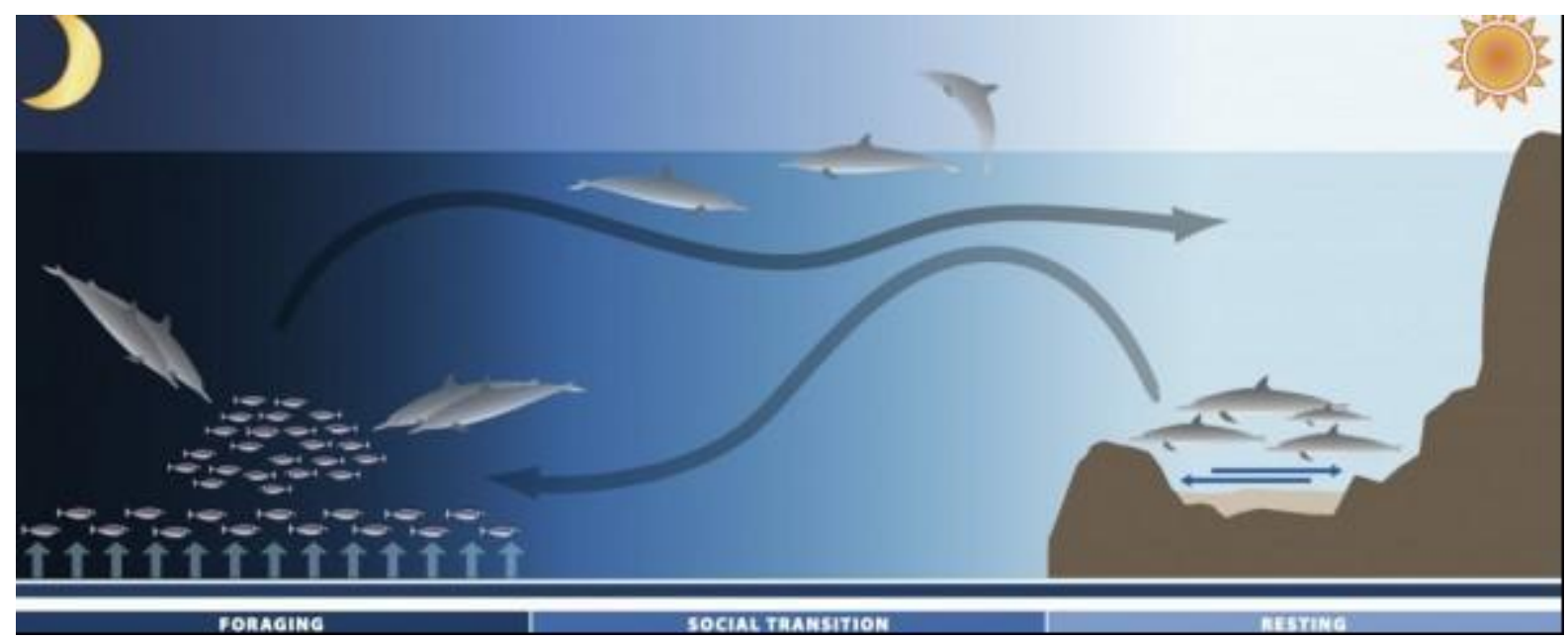

(Johnson 2011)

There is a large potential for human impact on spinner dolphins because of the species' behavioral pattern of using shallow, near-coastal areas as resting sites in the daily migratory cycle between these resting sites and deeper water feeding sites. Studies on the Hawaiian spinner dolphins indicate that their resting period can be critically interrupted and prematurely curtailed by approaching vessels and swimmers (Johnston and Bejder 2011; Würsig 1996; and Courbis and Timmel 2009). Interruption of these daily-resting periods in near-shore, shallow bays may negatively impact the physiology of the dolphins, and by extension, diminish their population. 
The National Marine Fisheries Service has established guidelines for recreational activities associated with marine mammal viewing that are consistent with the Marine Mammal Protection Act's (MMPA) regulations (NMFS Protect Dolphins Brochure). The MMPA makes it illegal to "harass, hunt, capture, or kill, or attempt to harass, hunt, capture, or kill any marine mammal." Since the spinner dolphin species is pantropical, it is useful to consider the impacts of vessel traffic and human interactions on the Hawaiian populations as models for studying other island-associated spinner dolphin populations, such as those found near Guam.

The purpose of this study is to document natural populations of marine mammals surrounding the island of Guam, with particular focus on spinner dolphins. This area of investigation is of particular importance due to the proposed expansion of the United States military on the island. According to an article in the Feb 9, 2012 issue of Defense Industry Daily, "Guam is likely to see between $\$ 400$ million and $\$ 1$ billion in military construction each year for a period of six to 10 years." Estimates made by the World Resources Institute describe military development projects budgeted at well over $\$ 10$ billion and which include a new Marine Corps base and airfield, a new Army base, new docking facilities for nuclear aircraft carriers, and expansion of existing Navy and Air Force facilities (The Defense Industry Daily, Feb 9, 2012). This proposed military development has received much attention in Guam, both negative and positive. It is clear that significant military personnel increases will have an impact on both the infrastructure and environmental status of Guam. A major consequence of this development is the projected increase in the use of shallow bays for both military training purposes and for tourist excursions to watch and swim with dolphins.

Prior to the authorization of any changes to the spinner dolphins' near-shore habitat, research needs to be conducted to establish baseline population estimates of the dolphins in the area and to determine how the spinner dolphins use the bays. This will ensure accurate predictions of environmental impacts. Previous studies of marine mammals near Shark Bay, Australia have documented decreased population sizes in relation to increased boating activity (Bejder et.al 2006). This current study represents the first effort to compose a marine mammal database to aid in the future collection of data on marine mammals, with specific emphasis on spinner dolphins around Guam. Using spinner dolphins as an indicator species, because of their near shore habitat usage and their relatively high numbers, will help management agencies and other stakeholders predict what possible effects increased military presence and ecotourism may have on these dolphin populations.

\section{METHODS}

\section{HISTORICAL RECORDS}

Prior to the collection of any field data, extensive historical searches of the literature were conducted to establish a historical timeline for determining which marine mammals have been identified in the waters surrounding Guam and the habitats they might be using. A careful review of the literature allowed more information about the commonly observed marine mammal species to be compiled along with single sightings, beaching, and stranding events. 
Historical data were also collected by communicating and collaborating with local resource agency personnel and more than 20 boat captains of Guam.

All previously recorded sightings, beachings, and other encounters were compiled from two comprehensive sources, one published and one field record. The published source was compiled by Dr. L. G. Eldredge in his 2003 article "The Marine Reptiles and Mammals of Guam." This record includes three decades of marine mammal encounters spanning the 1970s, 80s, and 9os. The relevant records from this report were transcribed from the text of the publication and entered into table form (Appendix A) to facilitate comparison with current data.

The other comprehensive source is the field record supplied by Brent Tibbatts, a Fisheries Biologist with the Division of Aquatic Wildlife Resources (DAWR) in Guam. A sample of this record, which contained sightings, beachings, and other encounters from September 7, 1962 throughl July 6, 2011, is also organized in table form (Appendix B). In addition to Brent Tibbatts, other resource personnel included staff of NOAA's National Marine Fisheries Service Pacific Islands Regional Office, (Valerie Brown, PIRO).

Any information obtained concerning marine mammals in the rest of the Mariana Archipelago is also included in the appendices. All available details surrounding the nature, location, date, or species involved in the encounters were recorded.

\section{CURRENT RECORDS}

\section{BOAT-BASED OBSERVATIONS}

The procedure used for photo documentation of spinner dolphin sightings was consistent with the Pacific Island Fisheries and Science Center (PIFSC) photo documentation and survey protocols. Photographic images were taken using a digital SLR Canon 60D camera fitted with a 100-300mm lens. Observations focused on Guam's Agat Bay, Apra Harbor, and included an allday series of multiple north-to-south trips along the west side of the island with Marie Hill, PIFSC Cetacean Specialist, and her research team. Sighting locations and geographical positioning system (GPS) locations were overlaid with NOAA's benthic habitat maps to determine the extent of marine mammal habitat use. A total of seven trips on vessels were made within the span of two weeks between July 5 and July 19, 2011. The eighth and final trip with Marie Hill and the PIFSC team took place at the beginning of August 2011. Information recorded during observational trips included species identification, group numbers, behavior, location, and general weather and water conditions. All eight photo documentation sessions were performed from the deck of ships of several different dolphin tour boat operators and dive boats.

At each site, we located a point of origin within a pre-existing macroplot study area managed by IAE, LCOG, or the City of Eugene. From the point of origin, we established a baseline transect based on the site descriptions provided by IAE. Using the systematic sampling method, we set up transects perpendicular to the baseline transect, with the first transect randomly located and each subsequent transect following at an equal interval of 4-5 meters. Along each transect, the 
first sample point was randomly located and each following point was spaced at an equal interval of 4-5 meters for a total of 200 sample points per study site. At each sample point, we collected data for topography, water level, vegetation height, and litter (fallen dead vegetation) depth.

\section{ANECDOTAL INTERVIEWS}

All of the 24 local fisherman and tour boat operators who provided observational opportunities were also interviewed in July and August 2011. This information establishes a broader understanding of seasonality, diversity, and location of key habitat areas for the spinner dolphins specific to Guam from the local perspective.

\section{RESULTS}

\section{HISTORICAL AND CURRENT DATA COMPARISONS}

The most common species, both as observed in the literature as well as in field encounters, was the spinner dolphin Stenella longirostris. Samples of these records are given in Appendix A and Appendix B. Eldredge reports a total of 13 cetacean species from the waters around Guam and the Mariana Islands. The boat-based sightings in the current study included three of the thirteenspecies: the Stenella longirostris - spinner dolphin; Stenella attenuata - pantropical - spotted dolphin; and Globicephala macrorhynchus - short-finned pilot whale. Brent Tibbatts (DAWR) documented a total of 23 marine mammal species. Appendix A also includes the more current sighting information updated from the boat-based surveys conducted in this study. These boat-based sighting events were recorded on eight non-consecutive days during the study period and are designated by asterisks. Field log sheets were submitted to NOAA's Pacific Island Regional Office (PIRO) to be added to ongoing data collection efforts by the Joint Institute for Marine and Atmospheric Research (JIMAR) at the University of Hawaii, Manoa.

All of the 24 local fisherman and tour boat operators who provided observational opportunities were also interviewed in July and August 2011. This information establishes a broader understanding of seasonality, diversity, and location of key habitat areas for the spinner dolphins specific to Guam from the local perspective.

\section{PHOTOGRAPHIC AND GPS DOCUMENTATION}

This study collected additional data on the eight field days using standard photo documentation and survey protocols developed by the NMFS, Pacific Islands Fisheries Science Center (PIFSC). Photographs were submitted to the Pacific Islands Photo Identification Network (PIPIN) database. Sample photographs of the distinctive individuals are included here as Appendix C.

Selected sighting locations for S. Longirostris and corresponding geographical positioning system (GPS) locations were combined with NOAA's benthic habitat maps. Boat track lines and dolphin locations are noted in Appendix D. Image $\mathbf{D}_{1}$ is the satellite image with boat tracking 
and $S$. Longirostris sightings and image $\mathbf{D}_{2}$ illustrates the same information overlaid with NOAA's benthic habitat map.

\section{ANECDOTAL INTERVIEWS}

Samples of the interviews with the local fisherman and dolphin tour boat operators frequenting the area are listed in Appendix E. This appendix includes the following for each boat based observations and marine mammal sightings: date and time of day, vessel, captain, number of individuals sighted, observations, and captain's comments-if any. These entries document numbers of individuals sighted, their direction of travel, and include the objective and subjective observations offered by the boat captains, including, in some cases, evidence of effects of dolphin-vessel interactions.

These records of observations, documented sightings, and combined anecdotal information provide supporting evidence for a circadian and seasonal pattern in the life of spinner dolphins on Guam as noted in other studies done in Hawaii by Silva (2009). Specifically, these data confirm the same known habitats of $S$. longirostris as reported for the Hawaiian spinner dolphin populations. The field observations and data presented by both the fishermen and the dolphin tour boat operators show that the key habitat used by Guam's spinner dolphins includes the use of sandy, shallow bays for daytime resting and transitional social behavior.

In order to measure microtopography at each site, we used a surveyor's level (Harrelson et al. 1994). First, we set up the tripod, and secured and leveled the instrument to ensure consistency in our measurements. Next, we took a backsight reading to the point of origin, which had an arbitrary elevation of 100 meters. The height of the instrument (HI) was then calculated by adding the backsight reading to the standard elevation value of 100 meters. At each sample point along each transect, a foresight (FS) was recorded. The elevation of each sample point was calculated by subtracting the foresight from the height of the instrument (HI FS = ELEV). At the approximate mid-point and end of the survey, we took another backsight to the benchmark to ensure the level had not moved or shifted significantly (Harrelson et al. 1994). In addition to measuring elevation, at each point we recorded the depth of standing water with the surveyor's rod to the nearest millimeter.

\section{DISCUSSION}

Spinner dolphins' reliance on near shore habitats for a critical resting stage in their circadian behavior renders them vulnerable to displacement by human activity. Ostman-Lind et al. (2004) studied specific times during the day when the Hawaiian spinner dolphins were particularly susceptible to disturbance. They found that human disturbance was highest in mid-morning, just when spinner dolphins were returning to rest. As the dolphins begin or end their resting period, they engage in aerial spinning and leaping behaviors that are noticeable from shore (Würsig et al. 1994) and therefore attractive to human spectator involvement. 
Ostman-Lind et al. (2004) also found that secondary resting areas, areas that had less boat traffic, were being utilized more than primary areas after boat traffic increased in the primary areas. This suggests that the dolphins had been displaced from their primary resting areas. The secondary resting areas, however, may not provide the same quality of rest or same amount of protection from predators, making them less preferable to primary rest areas.

During periods of rest, spinner dolphin behavior consists of synchronous dives and extended periods of swimming in quiet formation along the shallow bottom (Norris and Dohl 1980; Norris et al. 1985). Spinner dolphins sleep with one half of their brain at a time (Ridgway 2002). Figure 2 illustrates a brain scan from the right and left hemispheres during dolphin sleep. This alternation of resting and vigilance may be beneficial for protection against predation, indicating the importance of the spinner dolphin's resting environment. The shallow bays where resting occurs may be ideal for keeping watch for predator outlines, particularly sharks, against the sandy bottom (Perrin et al. 2009).

Figure 2: Dolphin sleep patterns

Dolphin sleep

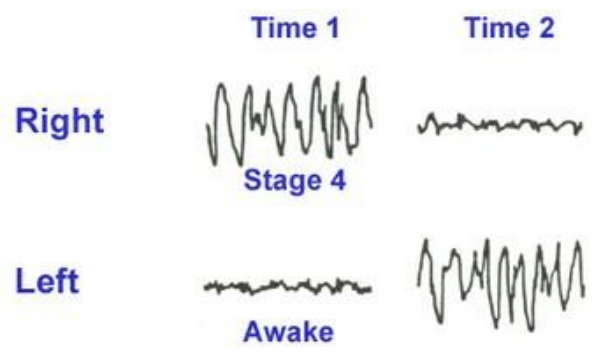

Image from http://www.colorado.edu/intphys/Class/IPHY3730/14biologicalrhythms.html

This study focuses on Agat Bay, one of the larger bays on the southwest side of Guam, but there may be many other ecologically sensitive areas critical to the health of marine mammal populations in the area. Studies on the influence of disturbances such as boating traffic and underwater sound pollution on spinner dolphins (Stenella longirostris) and other small cetaceans have shown that these marine mammals exhibit distinct behavioral responses to those disturbances beyond simply leaving the primary area for a secondary area. These behavioral responses include: changes in swimming speed, diving and aerial behavior, vocalization patterns, as well as movement patterns and overall avoidance of higher traffic areas (Corbis \& Timmel 2009). Similar behavioral responses were also noted in interviews with tour boat operators. These local experts further noted that they often observed similarly disrupted behavior when submarines and military hovercraft were training in the area.

Genetic and reproductive studies in the Hawaiian spinner dolphin populations have contributed to the body of evidence that indicates there is not regular interaction between populations of individuals that reside in consistent geographic locations. In fact, a recent study by population geneticist K. R. Andrews et al. (2010) suggested that gene flow, dispersal, and 
social structure of the Hawaiian spinner dolphin may be influenced by the availability of habitat and resources between islands. Photo-identification data collected during surveys in the waters surrounding Tutuila (American Samoa), indicate the presence of a resident population of spinner dolphins (Johnston et al. 2008). Approximately one third of the individuals within the photo-ID catalog were sighted in multiple years (Johnston et al. 2008). In addition, some of these individuals demonstrated "strong site fidelity and were encountered within only a few kilometers from one year to the next" (Johnston et al. 2008). Significant genetic distinctions were found between spinner dolphins sampled at five different islands and atolls, which included Hawaii, Oahu/4-islands, Kauai/Niihau, Pearl and Hermes Reef, Midway Atoll/Kure (Andrews 2009; Andrews et al. 2010). This indicates that spinner dolphins in these areas are residents of these areas and do not genetically mix with other populations. From anecdotal interviews of boat captains and field observations conducted in this study, it appears that there is also very limited mixing and interactions between separate pods of spinner dolphins around Guam. This means that each pod likely has a defined range and does not regularly interact with other pods. Any disruption of one pod's habitat therefore, could disrupt the integrity of the entire pod.

Photo-identification studies, over time, provide insight into habitat use and movements of individual cetaceans. Some species can be identified by naturally occurring markings on their bodies, often located on the dorsal fin, but also on flukes or the body. Photographic records of these scars, nicks, notches, or color patterns can be used to reliably identify individuals. Photographs are archived and combined with other data, including sighting location, group size and structure, and behavior. Individuals can be tracked over time and between locations on the basis of their unique photo-IDs (http://www.pipin.org/community).

Further documentation of pod integrity comes from the photo identification data. Data from the current study, specifically Agat Bay, indicate that the same individuals (those detailed in Appendix $\mathbf{C}$, the distinctive individuals which were identified by their markings) were associated with each other in the same location on multiple days throughout this study period. However, without genetic or multi-year, long term photo- identification data, it is difficult to establish connections between these individual dolphins as part of a stable, resident population. It is also difficult to estimate the size of the populations and corresponding key habitat that the dolphins occupy without long term studies that utilize the following methodologies: 1) visual and acoustic line transect surveys, 2) genetic and photo-identification studies both long-term and multi-year, 3) passive acoustic monitoring, and 4) habitat modeling and ecosystem observations.

Hawaiian spinner dolphins are identified as a stock of Pacific spinner dolphins (Norris et al.1994). If the situation in Guam can be compared to that of Hawaii, as it appears it can since spinner dolphins are pantropical and their behaviors and habitat requirements are essentially the same, then it will be important to minimize disturbances. Those disturbances include shoreline development, recreational boating traffic (with its resultant increased noise levels from motorized vessels), as well as military activity, involving ship traffic and training exercises, 
use of sonar, and detonation of explosives. Figure 6 illustrates geographical relationships of island-associated Pacific spinner dolphins emphasizing their pan-Pacific distribution.

Figure 3: Pan-Pacific distribution of island-related Pacific spinner dolphins

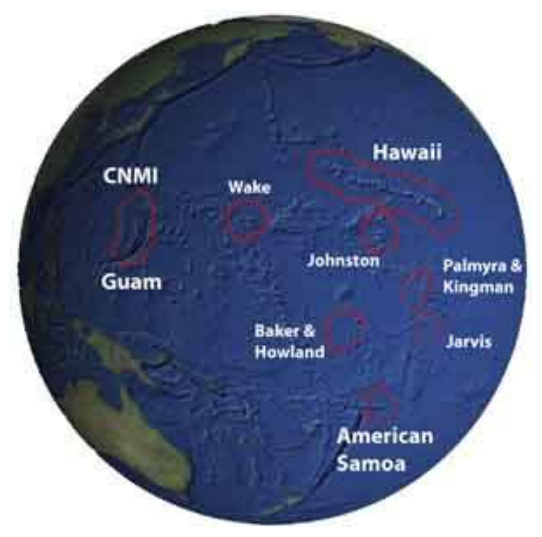

\section{IMPORTANCE OF THE MARINE MAMMAL PROTECTION ACT}

Spinner dolphin resting bays would likely be considered significant areas for survival of this species as defined by the Marine Mammal Protection Act (MMPA). The United States Congress passed the MMPA in 1972 in response to the following findings and policies, as quoted from the NOAA Fisheries Service MMPA Fact Sheet (MMPA, 1972):

- Some marine mammal species or stocks may be in danger of extinction or depletion as a result of human activities;

- These species or stocks must not be permitted to fall below their optimum sustainable population level (OSP);

- Measures should be taken to replenish these species or stocks;

- There is inadequate knowledge of the ecology and population dynamics; and

- Marine mammals have proven to be resources of great international significance.

According to Cicin-Sain \& Knecht (2000), the publically recognized issues that motivated this legislation were: (1) the decline in whale populations around the world, (2) harvesting of baby seals in Canada, and (3) increased public awareness of large numbers of dolphins, specifically spinner dolphins, being drowned as a result of commercial tuna fishing practices. However, according to a number of stakeholders, the MMPA is too ambiguously worded to protect the spinner dolphins from harmful interactions with humans in the coastal waters of the Hawaiian Islands (and other island populations) and legislative terminology such as "harassment," "take," and "disturb" was not sufficiently detailed in the original act (SAPPHIRE 201; http://www.nicholas.duke.edu/spinners/Total\%20Ecology). 
The MMPA recognizes that there are marine mammals threatened by human activities that do not involve traditional harvesting practices. As a result, public attitudes "shifted from a focus on their killing and material utilization to a more aesthetic interest in observing these creatures in the wild, in captivity, and in various media forms" (Lavigne, Scheffer et al. 1999). "Traditionally," marine mammals "were viewed mainly from a utilitarian perspective," and the focus was strictly on how they would be used as a resource (Lavigne, Scheffer et al. 1999). The legislative language exists to protect marine mammals, but, in practice, our interactions with nearly all marine mammals have changed since the law was first drafted, as has our understanding of their habitat requirements. It is also important to consider advancements in the scientific and popular understanding that all organisms are part of a larger system. Marine mammals are only one of many important components of marine food webs, which include complex interactions at a variety of levels. Thus, although MMPA also lists significant habitat as an important consideration in the protection of marine mammals and encourages the establishment of significant areas for protection (MMPA 1972), environmental impact is an increasingly critical area of study for understanding how marine mammals and their ecosystems can best be conserved. The specific habitat requirements of spinner dolphins put them at risk for degradation of population fitness and possible decline in numbers.

New attitudes and understandings that focus more on the non-consumptive use of marine mammals have led to "a dramatic increase in the viewing of marine mammals in their natural habitats" (Lavigne, Scheffer et al. 1999) and have raised a new set of concerns for the protection of marine mammal species. For example, in Hawaii there are multiple "Swim-with" programs that target spinner dolphins in their resting bays and, while they may raise public awareness and conservation efforts on behalf of dolphins, critically interrupt the dolphins' resting behavior. If the dolphins are not able to rest and recover from feeding offshore all night, this could prevent them from reaching or maintaining their optimum sustainable population (OSP)-one of the main objectives of the MMPA-by negatively affecting reproduction, foraging, and other normal behavior (Courbis and Timmel 2009). Harassment is defined by the MMPA as "Any act of pursuit, torment, or annoyance which has the potential to injure a marine mammal or marine mammal stock in the wild; or has the potential to disturb a marine mammal... by causing disruption of behavioral patterns" (MMPA 1972), and any study of human impact on marine mammal environments must take such a definition under serious consideration.

If there is too much tour activity in a bay and dolphins leave the bay, do not behave as they usually would, or change their behavior while they are in the bay in response to human activity (exhibit an increase or decrease in aerial behavior, etc.) then this may qualify as harassment. There is evidence that swim-with programs have had these types of effects on spinner dolphins in Hawaii (Courbis and Timmel 2009). If the spinner dolphin's resting bays are considered key habitat for the survival of island-associated populations, then they should consequently be considered significant areas for protection.

In addition to current military training, the study site of this project, Agat Bay, is also routinely used for boating, dolphin experiences, and jet ski recreation. If not timed and 
managed correctly, all of these human activities could pose a threat to the natural behavior, and ultimately, health, longevity, and sustainability of local dolphin populations.

\section{ECOTOURISM}

Viewing wild marine mammals has become a popular tourist activity, particularly in areas where the marine mammals are accessible, such as in the shallow, near-shore sandy bays frequented by island-associated spinner dolphins. Recent studies have raised concerns about the effect of increased ecotourism on the spinner dolphins in the Hawaiian Islands and elsewhere. Recreational activities in Hawaii and Guam have an increasing focus on tourist sightseeing activities, featuring small cetaceans, with a particular emphasis on viewing spinner dolphins as they come and go from their resting areas. The National Marine Fisheries Service (NMFS) has an official policy that encourages members of the public to view and enjoy spinner dolphins, but stipulates that these activities must be conducted in ways that are consistent with the provisions of the MMPA (EIS 2007). According to the Hawaii Tourism Authority (HTA), eco-tourism is "an economically, socially and environmentally sustainable activity that responsibly and authentically connects visitors with natural and cultural landscapes resulting in beneficial exchanges among these landscapes, the host community and the visitor" (Cusick et al. 2010).

The Pacific Islands Regional Office (PIRO) of the NOAA Fisheries Service initiated a dolphin human interaction Environmental Impact Statement (EIS, 2007) in response to concerns that human activities were negatively impacting Hawaii's spinner dolphins and held five scoping meetings in the fall of 2006 to collect comments from all stakeholders and any others interested in the issue (EIS 2007). There had been an increasing number of complaints that spinner dolphins were routinely disturbed by people who attempted to approach the animals near enough to feed and pet the dolphins. These interactions were conducted from motor-powered vessels, kayaks or in "swim-with-wild-dolphin" activities (EIS 2007), further contributing to their potential to disturb, or harass the dolphins in their key habitat.

Some general guidelines have been established for lessening the impact of human activities on dolphin populations. These are publicized by the NMFS in pamphlets and other forms of information distribution. The guidelines suggest safe distances and give reasons for not petting and feeding, or chasing marine mammals but have little impact for enforcement. Even if these guidelines were followed and effectively enforced, excess noise and boat traffic in the shallow bays as a consequence of Guam's projected military development could still further disrupt the resting pattern of these pods. Displacement from primary resting areas could negatively impact spinner dolphins by forcing them to use secondary resting areas that may not provide the same quality of rest or protection from predators and, consequently cause detrimental individual-level and population-level impacts to these dolphins by, for example, negatively affecting female fecundity.

This research shows that maintaining conditions for healthy populations of spinner dolphins in Guam should be paramount in considerations of human activity in their habitat, and similar priorities should guide efforts to maintain conditions for healthy populations in the Hawaiian 
spinner dolphins. In both cases (Guam and Hawaii), maintaining conditions for healthy environments necessary to conserve cetacean populations requires a sound scientific understanding of stock structure, abundance, habitat use, natural and anthropogenic threats, and estimates of reproduction and mortality rates. The MMPA's use of the concept and term "significant habitat" could be used as a mechanism to protect the shallow, near-shore sandy bays essential to spinner dolphins' successful survival in Guam. This is especially true when considering the evidence that Hawaiian spinner dolphins, another island-associated species, have been shown to leave a bay if they are disturbed (Norris et al. 1994).

This study's findings stress the importance of retaining minimized disturbances in key habitat areas for marine mammal populations. The results demonstrate that Guam spinner dolphins show a preference for clear, relatively shallow open water bays, with underlying, unconsolidated sediment (sandy bottoms). An increase in military use of shallow bays and dolphin-associated ecotourism could negatively impact resident populations of Guam's spinner dolphins if not managed properly. This population and behavioral data emphasizes the importance of preserving key habitat for spinner dolphins in Agat bay, both for the health of the spinner dolphins and for the sustainability of Guam's ecotourism industry.

The compounding evidence from this and many other studies in similar regions and environments emphasizes the need for increased documentation and information-gathering in order to preserve the natural structure and activity patterns of spinner dolphins. Such data will be particularly important in documenting further habitat use in other areas near Guam prior to any military expansion. Despite our best intentions, human actions may alter the natural patterns of spinner dolphin life, and consequently affect their sustainability as a species in a vulnerable, interconnected ecosystem. This is why we need to document, as completely as possible, the biology and ecology of island-associated spinner dolphins so as to minimize any detrimental human environmental impacts that may threaten these or any other marine mammal populations.

\section{ACKNOWLEDGEMENTS}

This work was supported by NOAA's Ernest F. Hollings Undergraduate Scholarship award to Robbie McNulty, 2010. 


\section{REFERENCES}

Andrews, K.R., Karczmarski, L., Au, W.W.L., Rickards, S.H., Vanderlip, C.A., Bowen, B.W., Grau, E.G., and Toonen, R.J. 2010. Rolling stones and stable homes: social structure, habitat diversity and population genetics of the Hawaiian spinner dolphin (Stenella longirostris). Molecular Ecology 19: 732-748.

Andrews, K.R. 2009. Barriers to gene flow in the spinner dolphin (Stenella longirostris). $\mathrm{PhD}$ dissertation, University of Hawaii, Manoa. 99 pp.

Bejder, L, Samuels,A., Whitehead, H., Gales, N., Mann, J., Connor, R., Heithaus,M., Watson Capps, J., Flaherty, C., and Kruetzen, M., 2006. Decline in relative abundance of bottlenose dolphins exposed to long-term disturbance. Conservation Biology. 20(6): 1791-1798.

Cicin-Sain, B. and R. W. Knecht (2000). The future of U.S. ocean policy: choices for the new century. Washington DC, Island Press. as cited in Johnston and Bejder, (2011) Spinner dolphin acoustics, population parameters and human impacts research. Retrieved from: http://www.nicholas.duke.edu/spinners/NtNFolder/History\%20and\%20Social\%20Construction\%20of\%20Spinner\%20Dolphins, Accessed March 26, 2012.

Courbis S. and G. Timmel (2009). Effects of vessels and swimmers on behavior of Hawaiian spinner dolphins (Stenella longirostris) in Kealake'akua, Honaunau, and Kauhako bays, Hawai'i. Marine Mammal Science. 25(2): 430-440.

Cusick, J, McClureb, B, and Coxc, L (2010), 'Representations of ecotourism in the Hawaiian Islands: a content analysis of local media', Journal of Ecotourism, 9(1): 21-35.

Defense Industry Daily, Feb 9, 2012 retrieved from http://www.defenseindustrydaily.com/usmilitary-gearing-up-on-guam-03011/, Accessed March 29, 2012.

Eldredge, L.G. 2003. The Marine Reptiles and Mammals of Guam. Micronesica. 35(36): 653660.

Environmental Impact Statement (EIS). (April 2007). Spinner Dolphin Human Interaction, Public Scoping Summary Report, National Marine Fisheries Service, Pacific Islands Regional Office, (PIRO).

Hill, M. C., E. M. Oleson, and K. Andrews. 2010. New island-associated stocks for Hawaiian spinner dolphins (Stenella longirostris longirostris): rationale and new stock boundaries. Pacific Islands Fish. Sci. Cent., Natl. Mar. Fish. Serv., NOAA, Honolulu, HI 96822-2396. Pacific Islands Fish. Sci. Cent. Admin. Rep. H-10-04, 12 p.

Johnston, D. \& Bejder, L. (2011). Spinner dolphin acoustics, population parameters and human impacts research. Retrieved from: http://www.nicholas.duke.edu/spinners. Accessed March 26, 2012.

Lavigne, D. M., V. B. Scheffer, et al. (1999). The Evolution of North American Attitudes toward Marine Mammals. Conservation and management of marine mammals. J. R. Twiss, R. R. Reeves and S. Montgomery. Washington, Smithsonian Institute Press. 
Marine Mammal Protection Act of 1972. 1972. 16 U.S.C. et seq. and 5O CFR part 216. http://www.nmfs.noaa.gov/pr/pdfs/laws/mmpa.pdf. Last accessed March 31, 2012.

National Marine Fisheries Service, Office of Protected Resources, Protect Dolphins: Admire them from a distance. http://www/nmfs.noaa.gov/prot.res.html. Accessed March 25, 2012.

Norris, K. S. and T. P. Dohl. 1980. Behavior of the Hawaiian spinner dolphin, Stenella longirostris. Fish. Bull. 77: 821-849.

Norris, K. Würsig, B. Wells, R. Würsig, W. Brownlee, S. (1994). The Hawaiian spinner dolphin, University of California Press. Berkeley, California.

Ostman-Lind, J., A. Driscoll-Lind and S.H. Rickards. 2004. Delphinid abundance, distribution and habitat use off the western coast of the Island of Hawaii. NMFS Southwest Fisheries Science Center Administrative Report LJ-04-02C. 28 pp.

Perrin, W.F., B. Würsig and J.G.M. Thewissen. 2009. Encyclopedia of Marine Mammals. Second Edition. Academic Press, Amsterdam.

Pacific Islands Photo Id Network. http://www.pipin.org/community

Ridgway, S. H. (2002). Asymmetry and symmetry in brain waves from dolphin left and right hemispheres: some observations after anesthesia, during quiescent hanging behavior, and during visual obstruction. Brain Behav. Evol. 60: 265-274.

SAPPHIRE (Spinner Dolphin Acoustics, Population Parameters, and Human Impacts Research), 2011. Nicholas School of the Environment, Duke University and Murdoch University. retrieved from http://www.nicholas.duke.edu/spinners/NtNFolder/History\%20and\%20Social\%20Construction\%200f\%20Spinner\%20Dolphins. Last accessed March 29, 2012

Silva F. and C. Rotador, (2009). Circadian and seasonal rhythms in the behavior of spinner dolphins (Stenella longirostris). Marine Mammal Science. 25(1): 176-186.

Spinner Dolphin Status and Research, Marie Chapla, Cetacean Biologist, Pacific Islands Fisheries Science Center retrieved from: http://www.fpir.noaa.gov/Library/PRD/Spinner\%20Dolphin/Spinner\%20PPT\%20revis ed.pdf, Accessed March 30, 2012.

Spinner Dolphin (Stenella longirostris) Status NOAA www.nmfs.noaa.gov/pr/species/mammals/cetaceans/spinnerdolphin.htm Accessed March 25, 2012.

Würsig, B. 1996. Swim-with-dolphin activities in nature: Weighing the pros and cons. Whalewatcher 30(1):11-15 


\section{APPENDIX A}

\begin{tabular}{|c|c|c|c|c|c|c|c|}
\hline Genus & Species & $\begin{array}{c}\text { Common } \\
\text { Name }\end{array}$ & Date & Island & Location & Who & Documentation \\
\hline \multicolumn{8}{|l|}{ Mysticeti } \\
\hline Balaenoptera & edeni & Bryde's Whale & $\begin{array}{l}\text { August } \\
\text { 31st, } 1978\end{array}$ & Guam & $\begin{array}{l}\text { 5oom north } \\
\text { of Sella Bay }\end{array}$ & $\begin{array}{l}\text { Eldredge, } \\
2003\end{array}$ & $\begin{array}{l}\text { (Davis, 1878) widely } \\
\text { distributed species, } \\
\text { speculative } \\
\text { decomposed carcas } \\
\text { washed ashore }\end{array}$ \\
\hline Balaenoptera & borealis & Sei Whale & 1972 & Saipan & $\begin{array}{l}\text { west of } \\
\text { island }\end{array}$ & $\begin{array}{l}\text { Eldredge, } \\
2003\end{array}$ & $\begin{array}{l}\text { (Horwood, 1987) } \\
\text { single specimen } \\
\text { sighting. }\end{array}$ \\
\hline Balaenoptera & borealis & Sei Whale & 1987 & $\begin{array}{l}\text { Northern } \\
\text { Mariana } \\
\text { Islands }\end{array}$ & $\begin{array}{l}\text { Northern } \\
\text { Mariana } \\
\text { Islands }\end{array}$ & $\begin{array}{l}\text { Eldredge, } \\
2003\end{array}$ & $\begin{array}{l}\text { (Horwood, 1987) two } \\
\text { tagged whales from } \\
\text { NMI where killed just } \\
\text { south of western } \\
\text { Aleutian isl. }\end{array}$ \\
\hline Megaptera & novaeangliae & $\begin{array}{l}\text { Humpback } \\
\text { Whale }\end{array}$ & $\begin{array}{l}\text { Febuary } \\
25,1991\end{array}$ & Guam & Uruno pt. & $\begin{array}{l}\text { Eldredge, } \\
2003\end{array}$ & $\begin{array}{l}\text { Eads pers. comm. } \\
\text { two individuals 10om } \\
\text { off reef margin. }\end{array}$ \\
\hline Megaptera & novaeangliae & $\begin{array}{l}\text { Humpback } \\
\text { Whale }\end{array}$ & $\begin{array}{l}\text { Febuary } \\
13,1991\end{array}$ & Guam & West coast. & $\begin{array}{l}\text { Eldredge, } \\
2003\end{array}$ & $\begin{array}{l}\text { Eads pers. comm. } \\
\text { three off west coast of } \\
\text { Guam. }\end{array}$ \\
\hline Megaptera & novaeangliae & $\begin{array}{l}\text { Humpback } \\
\text { Whale }\end{array}$ & $\begin{array}{l}\text { Febuary } \\
1991\end{array}$ & Saipan & off Saipan & $\begin{array}{l}\text { Eldredge, } \\
2003\end{array}$ & $\begin{array}{l}\text { (Darling \& Mori, } \\
\text { 1993) A group of } \\
\text { three were } \\
\text { photographed off } \\
\text { Saipan. }\end{array}$ \\
\hline Megaptera & novaeangliae & $\begin{array}{l}\text { Humpback } \\
\text { Whale }\end{array}$ & $\begin{array}{l}\text { Late } \\
\text { February }\end{array}$ & Rota & East coast & $\begin{array}{l}\text { Eldredge, } \\
2003\end{array}$ & $\begin{array}{l}\text { Stinson pers. comm. } \\
\text { A mother and her } \\
\text { Calf sighted off Rota's } \\
\text { east coast. }\end{array}$ \\
\hline Megaptera & novaeangliae & $\begin{array}{l}\text { Humpback } \\
\text { Whale }\end{array}$ & $\begin{array}{l}\text { January } \\
1996\end{array}$ & Guam & $\begin{array}{l}\text { Apra } \\
\text { Harbor, } \\
\text { entrance }\end{array}$ & $\begin{array}{l}\text { Eldredge, } \\
2003\end{array}$ & $\begin{array}{l}\text { (Anon, 1996) A group } \\
\text { of six or more } \\
\text { photographed at } \\
\text { entrance to Apra } \\
\text { harbor. }\end{array}$ \\
\hline \multicolumn{8}{|l|}{ Odontoceti } \\
\hline Ziphius & cavirostris & $\begin{array}{l}\text { Cuvier's } \\
\text { Beaked } \\
\text { Whale }\end{array}$ & 1972 & $\begin{array}{l}\text { Marianas } \\
\& \text { Bonin } \\
\text { Island } \\
\text { area }\end{array}$ & $\begin{array}{l}\text { Mariana \& } \\
\text { Bonin } \\
\text { Island area }\end{array}$ & $\begin{array}{l}\text { Eldredge, } \\
2003\end{array}$ & $\begin{array}{l}\text { (Masaki 1972) } \\
\text { cosmopolitan species } \\
\text { that has been } \\
\text { reported for these } \\
\text { areas. }\end{array}$ \\
\hline Physeter & macrocephalus & $\begin{array}{l}\text { Sperm } \\
\text { Whale }\end{array}$ & 1935 & $\begin{array}{l}\text { Micronesi } \\
\text { a }\end{array}$ & Micronesia & $\begin{array}{l}\text { Eldredge, } \\
2003\end{array}$ & $\begin{array}{l}\text { Townsend, charts } \\
\text { showing sightings } \\
\text { throughout the year } \\
\text { between } 1761 \& 1920\end{array}$ \\
\hline Physeter & macrocephalus & $\begin{array}{l}\text { Sperm } \\
\text { Whale }\end{array}$ & $\begin{array}{l}\text { September } \\
5,1962\end{array}$ & Guam & $\begin{array}{l}\text { Acho bay, } \\
\text { Inarajan }\end{array}$ & $\begin{array}{l}\text { Eldredge, } \\
2003\end{array}$ & $\begin{array}{l}\text { (Bordallo, 1965) 15m } \\
\text { longbeached albino } \\
\text { sperm whale. }\end{array}$ \\
\hline
\end{tabular}




\section{APPENDIX B.}

\begin{tabular}{|c|c|c|c|c|c|c|}
\hline Date & Species & $\begin{array}{l}\text { Scientific } \\
\text { Name }\end{array}$ & Location & Alive & Identification & Comments \\
\hline $9 / 7 / 1962$ & Sperm whale & $\begin{array}{c}\text { Physeter } \\
\text { macrocephalus }\end{array}$ & on shore & No & ???? & Acho Beach \\
\hline $7 / 15 / 1965$ & Sperm whale & $\begin{array}{c}\text { Physeter } \\
\text { macrocephalus }\end{array}$ & at sea & Yes & ???? & $\begin{array}{l}\text { Orote Point, } 3 \text { pods } \\
\text { of } 6,4 \text {,and } 3 \\
\text { individuals }\end{array}$ \\
\hline $3 / 25 / 1970$ & $\begin{array}{c}\text { Dwarf sperm } \\
\text { whale }\end{array}$ & Kogia simus & on shore & No & DAWR Staff & Asan \\
\hline May-74 & $\begin{array}{c}\text { Pygmy Killer } \\
\text { whale }\end{array}$ & Feresa attenuata & on shore & No & N. Drahos & confirmed, beached \\
\hline $12 / 6 / 1974$ & $\begin{array}{c}\text { Dwarf sperm } \\
\text { whale }\end{array}$ & Kogia simus & on shore & No & J. Villagomez & Rizal Beach \\
\hline $2 / 25 / 1978$ & $\begin{array}{l}\text { Humpback } \\
\text { whale }\end{array}$ & $\begin{array}{c}\text { Megaptera } \\
\text { novaeangliae }\end{array}$ & at sea & Yes & John Eads & $\begin{array}{l}2 \text { individuals } 100 \\
\text { meters offshore at } \\
\text { Urunao }\end{array}$ \\
\hline $8 / 31 / 1978$ & Bryde's Whale & $\begin{array}{l}\text { Balaenoptera } \\
\text { edeni }\end{array}$ & on shore & No & Gerry Davis & Unconfirmed \\
\hline $4 / 6 / 1980$ & $\begin{array}{l}\text { Melonheaded- } \\
\text { whale }\end{array}$ & $\begin{array}{l}\text { Peponocephala } \\
\text { electra }\end{array}$ & on shore & No & Terry Donaldson & Inarajan \\
\hline $7 / 6 / 1980$ & $\begin{array}{l}\text { Short-finned } \\
\text { Pilot Whale }\end{array}$ & $\begin{array}{c}\text { Globichala } \\
\text { macrorhynchus }\end{array}$ & on shore & No & DAWR Staff & Togcha \\
\hline no date & Spinner dolphin & $\begin{array}{c}\text { Stenella } \\
\text { longirostris }\end{array}$ & at sea & Yes & DAWR Staff & $\begin{array}{l}\text { seen from aerial } \\
\text { surveys frequently }\end{array}$ \\
\hline 1992 & Spinner dolphin & $\begin{array}{l}\text { Stenella } \\
\text { longirostris }\end{array}$ & on shore & No & DAWR Staff & Hilaan, lacerated \\
\hline no date & $\begin{array}{c}\text { Pantropical } \\
\text { Spotted Dolphin }\end{array}$ & $\begin{array}{c}\text { Stenella } \\
\text { attenuata }\end{array}$ & at sea & Yes & DAWR Staff & $\begin{array}{l}\text { seen from aerial } \\
\text { surveys frequently }\end{array}$ \\
\hline $8 / 2 / 1981$ & Killer Whale & Orcinus orca & on shore & No & DAWR Staff & Orote Point \\
\hline 9/17/1993 & Killer Whale & Orcinus orca & at sea & Yes & USCG & \\
\hline $2 / 9 / 1989$ & $\begin{array}{l}\text { Pygmy sperm } \\
\text { whale }\end{array}$ & Kogia breviceps & on shore & No & T. Sherwood & NSD \\
\hline $7 / 8 / 1990$ & $\begin{array}{l}\text { Common } \\
\text { dolphin }\end{array}$ & $\begin{array}{l}\text { Delphinus } \\
\text { delphis }\end{array}$ & at sea & Yes & Gerry Davis & Galvez \\
\hline no date & $\begin{array}{l}\text { Bottlenose } \\
\text { Dolphin }\end{array}$ & $\begin{array}{l}\text { Tursiops } \\
\text { truncatus }\end{array}$ & at sea & Yes & DAWR Staff & $\begin{array}{l}\text { seen from aerial } \\
\text { surveys frequently }\end{array}$ \\
\hline 2/13/1991 & $\begin{array}{l}\text { Humpback } \\
\text { whale }\end{array}$ & $\begin{array}{c}\text { Megaptera } \\
\text { novaeangliae }\end{array}$ & at sea & Yes & John Eads & $\begin{array}{l}3 \text { individuals off } \\
\text { East Agana }\end{array}$ \\
\hline $5 / 14 / 1993$ & $\begin{array}{l}\text { Short-finned } \\
\text { Pilot Whale }\end{array}$ & $\begin{array}{c}\text { Globichala } \\
\text { macrorhynchus }\end{array}$ & at sea & Yes & Greg Pangelinan & $\begin{array}{l}\text { Urunao, } \\
\text { approximately } 50 \\
\text { individuals at sea }\end{array}$ \\
\hline
\end{tabular}




\section{APPENDIX C. Distinctive Individuals - Stenella longirostris}
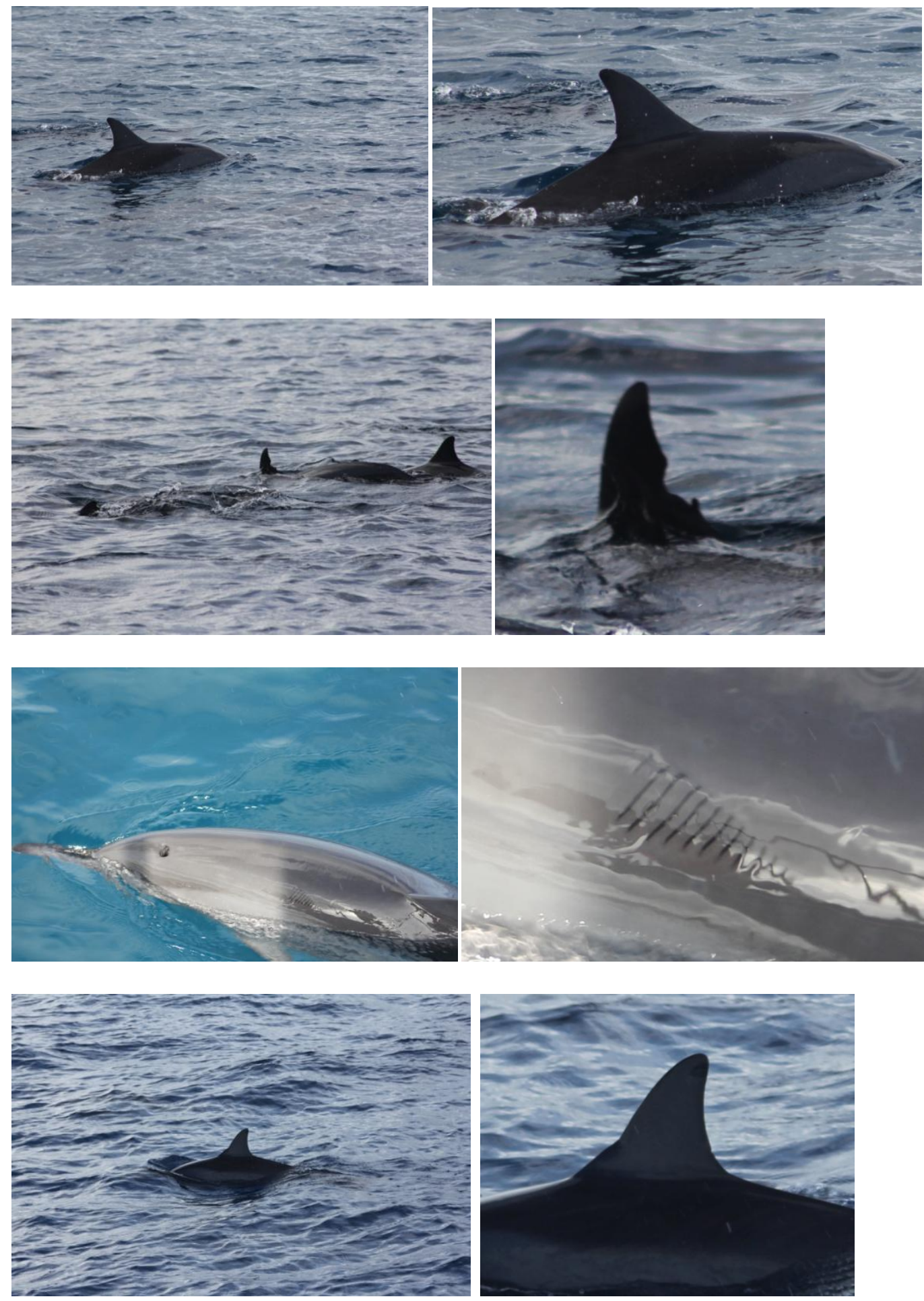

*All pictures were taken at Agat Bay by author 
APPENDIX D. $\left(D_{1} \& D_{2}\right)$
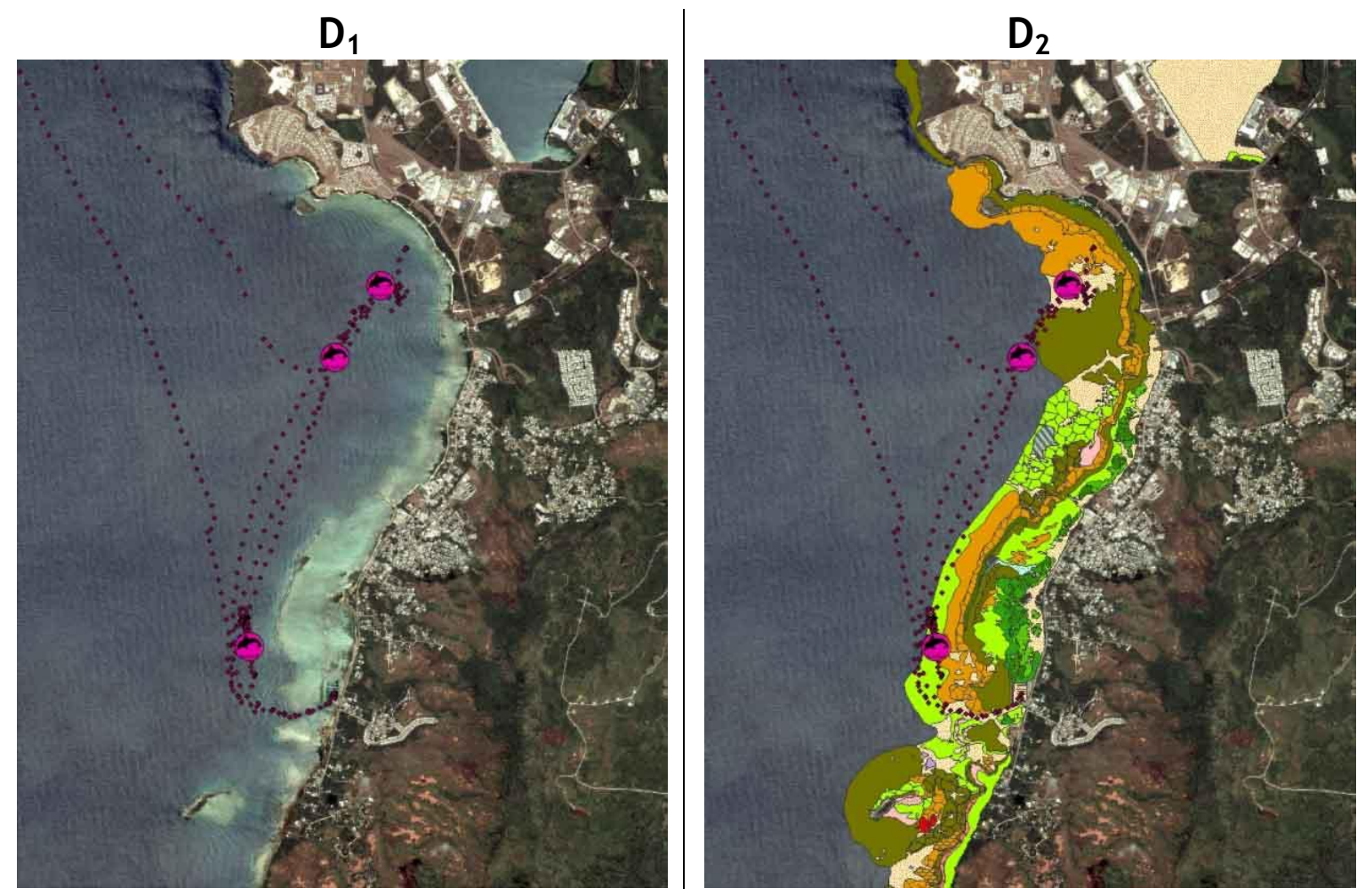


\section{APPENDIX E. Interviews and Marine Mammal Observations}

\section{July 5 2011,- Vessel: southern cross. Alan.}

- $\quad$ 1st sighting 8:52am-9:03 20 to 25 individuals, heading NE in Agat Bay

- $\quad 2^{\text {nd }}$ sighting 3:12pm-3:21 $\sim 18$ to 20 individual, heading SW in Agat Bay

\section{July 12 2011, - Vessel: Alii Nuii. Ken. Agat Bay}

- $\quad 1^{\text {st }}$ sighting 9:12am-9:27am 20 individuals, localized behavior playing in $\quad$ boats wake.

- $\quad 2^{\text {nd }}$ sighting 11:24am-11:39am 25 individuals, very shy/ not confronting the boats as they did earlier in the morning. Group split into two groups when approached by the Margarita boat. First group headed north towards Apica pt. second group headed southwest and group became very scattered and spread out.

- Late afternoon trip 3:30 - did not see any dolphins

\section{July 132011 - Vessel: Alii Nuii. Ken. Agat Bay}

- No Sightings, Too Rough. Sighted early in the morning over radio seen headed south in Agat

\section{July 162011 - Vessel Alii Nuii. Ken. Agat Bay}

- No Sightings, Clear/fair weather but still large surge and murky water. Relatively ruff inside the reef margin. Radio sighting - other boats saw dolphins beyond Anae island moving south.

- $\quad$ Captain Ken- said that sometimes the dolphins are just hanging around in deeper clear areas of the reef waiting for the water clarity closer to shore to clear up.

\section{July 17 2011- Vesel Southern cross. Jackie. Apra to Pitti}

- No Sightings. Went from Apra harbor to Pitti to set mooring for next dolphin cruise. Very big waves still so they needed to move the cruise location. Still no dolphins.

- $\quad$ Captain Ken- said that normally they see dolphins all around the island: Patti pt., Talofofo Bay, Santa Rosa Banks, Tumon, Pitti. However they mainly see dolphins in North Agat and Billy Bay though because these are more sheltered areas. When winds come from the north they generally move south, and when the winds come south they generally move north to the south pt of Apra. Ken also said that he has noticed an illeffect of the sub on the dolphins behavior they are never in proximity when the sub is around. He also said that the coast guard boat seems to be very disruptive to the dolphins natural behavior and that dolphins will generally move from the area when it is around. He speculates it is their sonar/pinging. 